DOI: https://doi.org/10.32839/2304-5809/2019-1-65-92

UDC 821.161.1-312-Makanin

Perynets Kateryna

University of Customs and Finance

\title{
THE PHENOMENON OF PROVINCIALITY IN THE CREATIVE ACTIVITY OF V. MAKANIN
}

Summary. The article is aimed at revealing the creative activity of the famous Russian writer V. Makanin in the context of provinciality problem. This phenomenon is defined as the property of personality and his existential self-identification in the modern society. It was found out that the ambivalence of attitude of Makanin heroes (as provincial and metropolitan) not only exposes their deep internal conflict but also becomes a peculiar indicator of their evolution. It is the phenomenon of provinciality clearly apparent in the works of the writer that predetermined his artistic discoveries and the possibility of forecasting the future of the country.

Keywords: provinciality, province/capital, existential self-identification, Makanin heroes.

Перинець К.Ю.

Університет митної справи та фінансів

\section{ФЕНОМЕН ПРОВІНЦІЙНОСТІ У ТВОРЧОСТІ В. МАКАНІНА}

Анотація. У статті розглядається творчість відомого російського письменника В. Маканіна в контексті проблеми провінційності. Даний феномен визначаеться як особистісна властивість людини та його екзистенціальна самоідентифікація в сучасному соціумі. Виявлено, що амбівалентність світовідчуття маканінських героїв (провінційність / cmоличність) не тільки показуе їх глибокий внутрішній конфрлікт, але й стає своерідним індикатором їх еволюції. Саме феномен провінційності, що чітко простежуеться у творчості письменника, визначив його художні відкриття та можливість прогнозування майбутнього країни.

Ключові слова: провінційність, провінція / столиця, екзистенційна самоідентифікація, герої Маканина.

Thesis statement. The phenomenon of pro1 vinciality, being current and controversial problem in scientific discourse be considered from various perspectives: cultural, philological, sociological, psychological, economic and so forth. The basic archetypic dichotomy - the center/periphery and also the center/province appears the dominant part of human life in cultural, economic, geographical plan as well as in self-identification of the personality. The last aspect finds its reflection in belles-lettres where the artist-demiurge is "a mirror, but alive mirror. He perceives only that what is the subject of direct perception from the world of appearances. But then the apprehended impressions in the live depth of his imagination come into some interaction, forming new combinations according to common vision of the world lying in the artist's soul. And here at the end of process the mirror gives it's reflection, the «illusion of the world»»" [4, p. 74]. Hereinafter, the creative activity of a famous Russian writer V. Makanin is a prime example where the provinciality appears as a measure of human qualities and the ways of identity searches in the world of artist.

The analysis of recent researches and publications. The phenomenon of provinciality is often considered in the context of province vision analysis by literary scholars in the works of various writers. Thus, in recent years there has been a tendency of selection the whole array of local texts in fiction with the core center of special space capable to transform and create unique shape of culture and mentality in general. There are quite a lot of such researches covering this problem in the Russian, Ukrainian and foreign literature to date. As a consequence, the scholars of Russian literature identified the so-called provincial text being in constant opposition to the center or the capital text a collection of articles Geopanorama of the Russian culture: Province and its local texts (Geopanorama russkoy kultury: Provintsiya $i$ yeye lokalnie teksty); V. Abashev, E. Popova, T. Yerohina, E. Galimova's publications, etc.).

The aspects of previously unsolved parts of problem. Notably, literary creation of Makanin is viewed in the context of Moscow text problem (K. Perynets, O. Kalashnikova, M. Selemeneva) where the issue of province and provincial hero is raised in opposition to capital space and the hero of Moscow. However, the phenomenon of provinciality is not declared as a separate problem by analogy with N. Gogol's creativity, though the capital "breaks (and forms) the optics" of Makanin, the duality of his self-identification promotes "break to the universal horizon" [1, p. 118].

Therefore, the goal of the article is an attempt to determine the provinciality as personal property and existential self-identification of human in the modern society in Makanin's creativity. The object of research is the provinciality phenomenon in writer's prose, the subject - provinciality as the characteristic of person's identity, defining his valuable purposes.

Statement of basic materials. The beginning of Makanin' creativity is connected with Moscow where he came to study from the far Ural town of Orsk in $1950^{\text {th }}$. The development of capital as the spaces of new opportunities and prospects, updating traditional opposition of two divergent mental attitudes, the systems of norms and rules begins since then. This problem is already arisen in the first novel of writer Straight light (Pryamaya liniya) (1965) where the image of Moscow is getting through a prism of perception the main hero Volodya Belov, the provincial for 
whom the capital is seen as cherished Paradise and where the straight line of fate is aimed to. It is since the 1960s of last century, Moscow, being the symbol of success and wealth, remains alien space, aggressively rejecting no-Moscow resident for him and the majority of Russians.

The autobiographical component is shown in the life story of main hero of the novel who came to study to Moscow from Ural as well as Makanin, got the higher mathematical education and remained in Moscow after the graduation, and, as well as Makanin, is going through difficult process of "integration into Muscovites" that is obviously highlighted by the narration from the first-person.

The image of his Muscovite friend with the speaking surname Knyazegradsky is conversed to Belov (as a hint to the Belaya River), first of all, by the birthplace: Muscovite / provincial. The binarity of their life perception in the city is reflected as at household level (existence / absence of the house, habitualness / strangeness to transport problems, etc.), as on existential one (acceptance / rejection in working collective, confidence / frustration in the mental plan).

The opposition capital / province defines also the motive repertoire of Straight line connected with the theme of conquering Moscow by provincials emerged in the second half of the XX century (V. Chernykh Moscow does not trust tears (Moskva slezam ne verit), works by I. Grekova). Makanin shows drama modifications of such a "conquest": the motive of provincial's envy to the Muscovites caused by their permit to Paradise only by birthright in First-throned, the motive of luck / mischance (latently specified through the antipodes of the provincial Volodya and the Muscovite Kostya); motive of fear above the capital and human crowd capable "to absorb" both the hero, and his family: "I was not lucky. Why? Why, mother? Let it be me, but whether you, old, will arrive, come running here to Moscow and will look for me, pushing among people and asking where and what?..” [11, p. 263]. But the main transformation of Moscow conquest theme by the provincial is revealed through the motive of memory / melancholy for native Ural places which is key for the world concept in the first novel of writer. The hero understands that Moscow environment is ruthless and aggressive because "the great city does not trust tears" [11, p. 257]. Provincial attitude of makanin character does not allow him to get used and accept severity of city's life that defines its internal conflict.

Therefore, the house of the childhood and memories of mother become that spiritual spring from which Volodya draws strength for soul peace and, thus, the provinciality can be considered as its personal quality, the indicator of its self-identity. Misalignment of attitude between provincial and Moscow residents is resulted in that Belov isolates oneself promptly from collective, crowd of ordinary Muscovites. We cannot but agree with V. Ivantsov's view, that this hero should be seen as the unique personality, opening the gallery of similar characters in Makanin's works [3, p. 67].

In prose of $1970 \mathrm{~s}$ the novelist continues to endure provincial heroes who address the cap- ital as the topos of time (Old books (Staryye knigi), Pursuit (Pogonya) and On the first breath (Na pervom dyhanii)), the topos of love affairs and disappointment (On the first breath). However, it is modeling of the so-called "middle" person (L. Anninsky's term) absorbed by routine life in the city space becomes the specific belles discovery of this period. Thus, provincial Klyucharev, the main character of The story about the old settlement (Istoriya o starom poselke) (1974) understands that he achieved much in his life and estimates oneself not without pleasure: "Klyucharev comes out of the subway. The shop. Show-windows. Klyucharev goes along enormous glasses, and his reflection is next to him. Thirty years. Prompt stride. A portfolio in the hand. Specifics of the face. ... a certain authority among people. Quite dense, biting speech (necessarily on occasion!) and rather ordinary wage" [8, p. 97]. His success is emphasized by the existence of own house as one of decisive factors for getting the status of "new Muscovite", but settled and calm being of his family where all is figured, "all is in places" discloses the "self-passing of life" determined by M. Lipovetsky as "thoughtless inertia of daily occurrence, banal madness of everyday life" [5, p. 148]. The rhythm of the big city consumed the provincial Klyucharev so deep that he has no time to visit his sister who "lives in Khimki, and they meet not often though she is native person" [8, p. 121]. Instead, the hero (in attempts to prove the status of "the new Muscovite") "exploits" "foreign" topos - the apartment of help-mate Natasha where their common acquaintances gather. The quarrel and a breakdown of these people promotes changes of values and understanding that it is difficult for him to adapt in capital space where "it appears, there are homesteads, villages and settlements" [8, p. 171]. The motive of loneliness and lostness of the provincial in the capital brings the novel closer to the plot of "Straight line". Like Belov, Klyucharev tries to look for harmony and the lost sense of life in the memories of native places, childhood, family. Filled with heat and sadness these memories of past save from desperation. The same function is carried out also by telephone conversations with parents as a certain communication with childhood and life in the settlement, though parents moved to other city long ago. It is remarkable that the character distances itself from the Muscovite wife and the son who do not understand his feelings and rushes. The similar parallel is outlined even at the physical level: unlike other members of the family, Klyucharev has good health that he accounts for "the last link of the Old Settlement, high quality of genes and natural selection" [8, p. 177].

Specific escapism of the hero is not single but is duplicated by the history of his twin Anikin that gives to a problem general nature. Achievement of the desirable ideal space, ruined, however, under the influence of time and economic changes, becomes the culmination of the work. The destroyed and left Old Settlement becomes a symbol of spiritual gap with the native land, and in a realistic plan displays the accruing processes of urbanization and decline of small settlements: "Klyucharev wan- 
ders and catches every minute of himself that he can't be integrated with this extinct place" [8, p. 183]. The final remains open, leaving the possibility of releasing "the middle person" from the fetters of city monotonous existence. The way towards freedom and finding the lost space of the Paradise conducts to sources, to native provincial stretch of the far Urals.

Many motives, the ideas, problems, innovative esthetic discoveries of early prose were developed by the author in the works of $1970-1980$ th years. In particular, further anatomization of "life self-flowing" of "the middle person" conducted with microscopic accuracy becomes a first-priority literary task of the writer. Moscow becomes the space dwelling of the "new" hero (both the provincial, and native Muscovite) in the majority of works. The topos of the Ural places gradually goes to the periphery of the narration that demonstrates changing of an existential vector.

Whereas the provincials of early works, who get into the conflict with the Moscow environment, had the strength to come back home, then at this creative stage they are helpless and tormented with doubts. The motive of not-return to native places is also foregrounded. For example, in the novel The portrait and around (Portret vokrug) (1978) some friend of Igor Petrovich, living in Moscow, nevertheless, "was endlessly groaning for the native places: he was the Uralsborn. He did not accustom to the big city, grieving and twitching, however, hasn't come back to the native land. Non-refoulement was the person's contradiction and his main highlight" [9, p. 7].

Most often Makanin shows quite fast change of a habitual lifeway of outsider heroes, demonstrating the addiction to the mechanism of megalopolis tempo-rhythm by this. Kolya Anikeev (Forerunner (Predtecha), 1982) is overwhelmed with the fuss of big city, but decides to remain in it though he "still liked to read about the village at night and about winter barking, feeling his heart squeezing in flush of affection" [10, p. 97]. But pastoral motives are fading as soon as the hero achieves success in journalism. The Ural provincial, similar to many other visitors, was absorbed by the whirlpool of life "self-passing", as he "lived in the city. Now - as all" [10, p. 242].

The heroes of this period, unlike characters of early prose, cannot be satisfied by the topos of one-room apartment - they seek, as a rule, for exchange or purchase of the spacious two-room apartment, dacha, the car. The label "live closely, have people in kitchen" pushes the hero of the novel Portrait and Around on acquisition the other housing, thereby involving him in infinite circulation of wealth creation: "We moved from oneroom to two-room apartment. The flat is spacious. I went from one room to another and there was a feeling of remote borders - the feeling of breadth ... Now new furniture was needed, for sure" [161, p. 277]. Thus, fight for coveted Moscow square meters becomes the sense of life of the "middle" people. There is no place left for sincere feelings and family values which are completely replaced with the household problems and routine habits in the live space of Makanin heroes that doom them to loneliness and misunderstanding.
In the fiction of 1990-2000th provincial heroes gradually come on the periphery, completely merging with city dwellers that confirms once again the autobiographical nature of Makanin's creativity who becomes, as well as his characters, "the native one" in city space, but all the same introduces the provincial attitude in his works.

The motive of fight for square meters, making the sense of many provincials' life is also revealed in the central novel of Makanin prose The underground, or the Hero of our time (Andegraund, ili Geroy nashego vremeni) (1998). But in a microcosm of Moscow life shown as a spatial image of an apartment house, the provincials have the latest niche to play: "Out-of-towners for hire lived in the wing "K": wetback" [6, p. 46]. Over the time, however, they are also adapting to the capital life, taken, as well as others, in captivity of "life self-passing", merging with a gray mass of "middle" Moscow inhabitants.

Autobiographical as a characteristic feature of makanin art thinking, is also shown in the image of old man Alabin, the main hero of the novel Fright (Ispug) (2006). He calls himself "the Ural old man" [7, p. 357] and also "the technician by training" [7, p. 183] who moves to Moscow region in his old age where he lives as a watchman in presented lean-to. But Alabin, unlike other Makanin heroes, does not only loses, but also feel the communication with the native Ural area at all, the memory of which is completely replaced with space of the settlement near Moscow. An ideal topos, the image of Paradise which is so persistently looked for by all characters of the writer throughout a long creative way is found (already in old age) in the quiet suburban territory, but not in vanity of the huge megalopolis. Got used to isolation of capital apartments, the hero, at last, can feel beauty and harmony of life: "I found myself (!) here... In space of dachas. In these forests around Moscow... In this Moscow river... Here $\mathrm{I}$ am a person. Here I am alive and is still fit for something alive" [152, p. 370]. The angle of a provincial view of the events accurately fixes again those problems and the conflicts which seem insignificant or norm for the city dweller.

Summary. The phenomenon of provinciality as characteristics of the person's mentality is shown in each period of Makanin's creativity. It is precisely this characteristic allows to track evolution of his hero - from the Ural rebel to the "middle", and then "little" person. On the one hand, "naivety, backwardness, peripherality, and simplicity" of provincial attitude is overturned [2], but, on the other, the true cultural wealth is lost in the pursuit of the status "the capital resident" that is why Makanin's "new Muscovites" are so lonely and unfortunate. This permanent internal conflict, in our view, played a significant role in a spiritual and creative change of the writer, thus promoted his growth. Belles discoveries of Makanin (such as "middle" person, the transformation of "little" man, "self-passing" of life, creation of myth-parables about country's future) are determined a lot by his external viewpoint, from the position of other mental foreshortening which allowed "to anatomize" precisely daily occurrence and to predict further evolution of the personality. 


\section{References:}

1. Akimova M.S. (2017). Gogol, ili Provincial v stolitse: ot Malorossii do Peterburga [Gogol, or the Provincial in the capital: from Malorossia to St.-Petersburg], Nauchny dialog, no. 6, pp. 113-124 (in Russian).

2. Balyushina U.L. (2017). Provincialnost kak lichnostnoe svoistvo: socialno-filosovskii aspekt [Provinciality as personal property: social philosophic aspect], Obshchestvo: filosofiya, istoriya, kultura, no. 7, available at: http://dom-hors.ru/rus/files/arhiv_zhurnala/fik/2017/7/philosophy/balyushina.pdf (accessed 11 January 2019) (in Russian).

3. Ivantsov V.V. (2007). Prostranstvenno-vremennaya organizatsiya hudozhestvennogo mira V. S. Makanina [Spacetime arrangement of imaginative world of Makanin V.S.], PhD diss., St Petersburg State University, 239 p. (in Russian).

4. Korolenko V.G. (2014). Stat'i, retsenzii, ocherki [Articles, reviews, essays], Moscow, Direct-Media Publ., 389 p. (in Russian).

5. Lipovetskiy M.N. (1985). Protiv techeniya. Avtorskaya pozitsiya v proze Vladimira Makanina [Against the tide. Authorial position in the prose of Vladimir Makanin], Ural, no. 12, pp. 148-158 (in Russian).

6. Makanin V.S. (2008). Andegraund, ili Geroy nashego vremeni [Undergraund, or the Hero of our time], Moscow, Geleos Publ., 608 p. (in Russian).

7. Makanin V.S. (2006). Ispug [Fright], Moscow, Geleos Publ., 416 p. (in Russian).

8. Makanin V.S. (2001). Istoriya o starom poselke [The story about old village] in V.S. Makanin, Liniya sud'by i liniya zhizni. Romany [V.S. Makanin, The line of destiny and life. Novels], Moscow, ZAO Tsentrpoligraf Publ., pp. 91-184 (in Russian).

9. Makanin V.S. (1978). Portret I vokrug [The portrait and around], Moscow, Sovetskiy pisatel Publ., 280 p. (in Russian).

10. Makanin V.S. (2010). Predtecha [Forerunner], Moscow, Eksmo Publ., 288 p. (in Russian).

11. Makanin V.S. (1979). Pryamaya liniya [Straight line] in V.S. Makanin, Klucharev i Alimushkin. Roman, rasskazi [V.S. Makanin, Klucharev i Alimushkin. The novel, stories], Moscow, Molodaya gvardia Publ., pp. 153-285 (in Russian). 